\title{
Influence Of Labor Market Institutions On Female Youths' Access To Formal Employment In Kenya's Private Sector
}

\author{
Joseph Ogutu Owino \\ Department of Educational Communication and Technology \\ University of Nairobi, KENYA \\ Esther Awuor Owino \\ Department of Educational Communication and Technology \\ University of Nairobi, KENYA \\ Paul Amolloh Odundo \\ Department of Educational Communication and Technology \\ University of Nairobi, KENYA
}

\begin{abstract}
Kenya's demographic trends have resulted in an eminently young population structure. Unfortunately, there is high prevalence unemployment among youths in Kenya. Female youths are the most adversely affected by unemployment. As a result, a good number of them have resorted to seeking employment in the informal sector which in most cases does not provide adequate earnings. It was therefore important to examine the influence of labour market institutions on female youths' access to employment in the private sector. The study was based on qualitative and quantitative research methodologies. A survey questionnaire and a key informant's guide were used in collection of quantitative and qualitative data on labor market institutions in Kenya respectively. The study findings revealed that majority of women relied on social networks in gaining employment in the private sector. The findings further indicated that majority of women employees worked under oral contracts that did not guarantee good working conditions. Therefore, existing institutions in the labor market, such as terms and conditions of employment and poor implementation of labor laws hindered female youths' access to formal employment in the private sector.
\end{abstract}

Keywords: labor market institutions, female youths, access, formal employment

\section{INTRODUCTION}

Labor market institutions refer to policy interventions or collective organizations that determine wages and employment (Holmlund, 2013). Laws, practices, policies and conventions that fall under the umbrella of labor market institutions determine the type of contracts that are permissible. The creation of labor market institutions is usually justified based on imperfect information, uneven market power (between employers and workers), discrimination, and inadequacies of the market to provide insurance for employment-related risks (Bercherman, 2013). The influence of labor market institutions on employment has been approached from two differing perspectives. These perspectives are often referred to as the 'distortionist' and 'institutionalist'.

The 'distortionists' view labor regulations as a cost and interference in the market process that impede efficiency and discourage competition and investment (Fontana \& Paciello, 2007). According to this perspective, regulations inevitably lead to rent extraction by politically influential 'insiders', who gain at the expense of those who have to pay more for goods and services, and of those who end up without jobs (Fontana \& Paciello, 2007). Since they create a 
wedge between the earnings of insiders and outsiders, they can be expected to increase inequality. By contrast, those who support labor market interventions (the institutionalists) argue that labor market interventions could potentially increase efficiency and lead to a better economic performance (Bercherman, 2013). They further contend that labor market institutions are associated with less inequality because they favor workers at the expense of employers. This study sought to investigate the influence of labor market institutions on female youths' access to formal employment in the private sector in Kenya. The specific issues examined were labor networks and employment terms and conditions in private sector organizations.

\section{LITERATURE REVIEW ON THE INFLUENCE OF LABOUR MARKET INSTITUTIONS ON WOMEN'S ACCESS TO EMPLOYMENT}

Labor legislations can directly or indirectly impose restrictions on women's access to work (Sanja \& Breslin, 2010). For instance, in some societies, women are not allowed work in the formal sector unless permitted by their spouses (Sanja \& Breslin, 2010). Working conditions, such as regulations on working hours, maternity leave and remuneration also influence participation of women in the formal sector (Rodgers \& Berik, Asia's Race to Capture Post-MFA Markets: A Snapshot of Labour Standards Compliance and Impacts on Competi, 2006). Existing differences in parental leave between men and women could increase the perceived cost of employing women and reduce their employment opportunities. According to the International Labor Organization (1998), implementation of labor laws has remained a challenge in many countries. In Korea, for example, only a few firms in the manufacturing industry have instituted the system of maternity protection (Sirin, 2003; Hensvik \& Skans, 2003). This outcome could reflect either poor compliance among firms or lack of workers' awareness of the policy.

Standard models of the labor market focus on individual characteristics, such as human capital levels, but usually disregard group characteristics, such as the pattern of social connections between individuals in the market. Yet, empirical accounts show that the matching of individuals to jobs is widely influenced by networks of interpersonal ties, particularly the young people. Social contacts help job seekers to find jobs, and employers to find employees (Calvo-Armengol, 2005). Social networks convey rich and trustworthy information across both sides of the labor market. As such, they constitute a cost-effective search channel for labor market information among job seekers and employers. Firms find it beneficial to use social contacts because they enable them to find their desired recruits. Thus, social networks serve as a direct means to reduce the uncertainty regarding how well suited the capabilities of a certain worker are for a particular firm by providing credible information.

According to Montgomery (1991), many companies like recruiting associates of industrious employees with the assumption that friends exhibit similar characteristics. Casella and Hanaki (2006) quoted in Hensvik and Skans (2013), further noted that many employers like hiring through personal referrals because they are cost effective. Moreover, social networks enable employers to extract surplus information about recruits. A part from being beneficial to employers, inexperienced workers can secure jobs through social networks. For example, relatives and friends often assist fresh graduates in getting jobs by linking them with employers (Hensvik \& Skans, 2003).

Organizational research evidence indicates that men and women often use different social networks to access labor market information. Existence of various social networks may result into diverse labor market outcomes for men and women. Additionally, barriers to being part of the social networks often limit women's ability to gather and share information (World Bank, 
2010). Although labor market information is usually communicated through social networks, women are less likely than men to participate in nonexclusively female networks. Thus, gender based differences in access to labor market information through social network can hinder women's access to economic opportunities (World Bank, 2010).

\section{Problem Statement}

Formal employment is one of the most plausible ways through which women can overcome socio-economic challenges (Corner, 2011). Globally, formal employment is widely recognized as an important vehicle for raising the status of women and promoting gender equality between women and men (Corner, 2011). In Kenya, the private sector serves as a major creator of both formal and informal employment. However, challenges in the labor market institutions have affected ability of young people to access jobs in the private sector. Previous labor force studies in Kenya have attributed the imbalance to personal characteristics (Wamuthenya, 2010; Suda, 2002). However, there is paucity of information about the specific institutional constraints that hinder young women in Kenya from accessing employment. This study aimed at investigating the institutional factors in the labor market that restrict female youths from accessing employment in the private formal sector. This study focused on the private sector because it is the major creator of formal employment in the country. In so doing, it aimed at generating new knowledge to the existing literature on female youth employment.

\section{Overall Objective of the study}

The overall objective was to examine how labor market institutions restrict female youths from accessing formal employment in Kenya's private sector.

\section{Specific Objective of the study}

I. Examine the influence of terms and conditions of work on female youths' access to formal employment in Kenya's private sector.

II. Analyze the influence of social networks on female youths' access to formal employment in Kenya's private sector.

\section{Conceptual Framework}

The conceptual framework in figure one illustrates how the independent variables (labor market institutions and social networks) both influenced the dependent variable (female youth access to formal employment in private formal sector in Kenya). Based on the reviewed literature, the conceptual framework hypothesized that labor market institutions influenced female youth's access to formal employment. 


\section{Independent Variables}

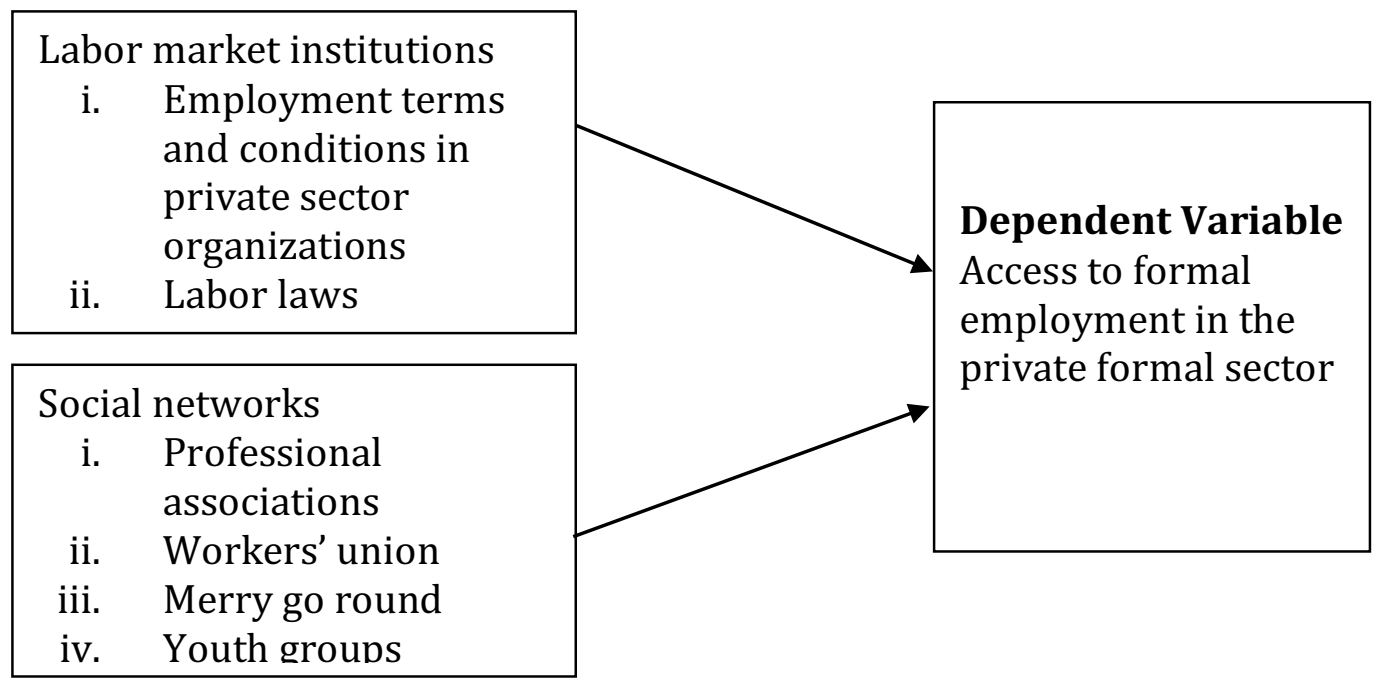

Figure 1: Author's conceptualization

\section{Study Sites}

METHODOLOGY

The study was carried out in East Kanyada location of Homa-Bay County and Kawangware Town of Nairobi County. Kawangware is a sprawling urban centre with a resident population of 113286 people and geographically covers 3.9 square kilometers (KNBS, 2009). Most of the inhabitants of Kawangware are low-income earners in the private sector and live in informal settlements. On the other hand, East Kanyada location is a remote village in Homa-Bay County with a geographical area of 104.1 square kilometers. It has a resident population of 37900 people (KNBS, 2009). Majority of its inhabitants are peasant farmers, but a few carry out smallscale retail businesses locally.

\section{Study Population}

The research population targeted women aged between 18 and 35 years in Kawangware town and East Kanyada location. Table 1 provides a summary of the population distribution in the areas of study.

Table 1: Population distribution in both Kawangware town and East Kanyada location

\begin{tabular}{|l|l|l|l|l|l|}
\hline \multicolumn{2}{|l|}{ Kawangware Location } & \multicolumn{2}{l|}{ East Kanyada Location } \\
\hline $\begin{array}{l}\text { Sub- } \\
\text { Location }\end{array}$ & $\begin{array}{l}\text { Male } \\
\text { Population }\end{array}$ & $\begin{array}{l}\text { Female } \\
\text { Population }\end{array}$ & Sub-Location & $\begin{array}{l}\text { Male } \\
\text { Population }\end{array}$ & $\begin{array}{l}\text { Female } \\
\text { Population }\end{array}$ \\
\hline Gatina & 24,747 & 21,125 & Kothidha & 4,200 & 4,702 \\
\hline Kawangware & 34,683 & 32,731 & Kanyach-Kachar & 3,609 & 4,129 \\
\hline & & & $\begin{array}{l}\text { Kalanya- } \\
\text { Kanyango }\end{array}$ & 6,965 & 7,562 \\
\hline & & $\begin{array}{l}\text { Kobwola- } \\
\text { Kogwang }\end{array}$ & 3,204 & 3,529 \\
\hline Total & 59,430 & 53,856 & & 17,978 & 19,922 \\
\hline
\end{tabular}

Source: 2009 Kenya Population and Housing Census Report Vol 1A

\section{Sample Size}

Proportionate sampling method was applied to ensure equal participation of respondents from all the sampled locations. Two locations were purposively selected because of their diverse 
demographic characteristics and socio-economic system. A sample size of 150 respondents was chosen through proportionate sampling method. Table 2 and 3 provide proportional samples for each location and sub-location respectively.

The sample for each Location was derived by:

Sample for Kawangware $=$ Total Population of females in Kawangware Location $\quad \times 150$

Total population of females in Kawangware + East Kanyada Locations

Sample for East Kanyada $=$ Total Population of females in Kawangware Location $\times 150$

Total population of females in Kawangware + East Kanyada Locations

Table 2: Proportional Sample for each Location

\begin{tabular}{|l|l|l|}
\hline Location & Total Female Population & $\begin{array}{l}\text { Proportional Sample Per } \\
\text { Location }\end{array}$ \\
\hline Kawangware & 53,856 & 109 \\
\hline East Kanyada & 19,922 & 41 \\
\hline Total & 73,778 & 150 \\
\hline
\end{tabular}

Source: Kenya National Bureau of Statistics Census Report, 2009.

Table 3: Proportional Sample for each Sub-Location

\begin{tabular}{|l|l|l|l|l|l|}
\hline Kawangware Location & \multicolumn{2}{l|}{ East Kanyada Location } \\
\hline $\begin{array}{l}\text { Sub- } \\
\text { Location }\end{array}$ & $\begin{array}{l}\text { Female } \\
\text { Population }\end{array}$ & $\begin{array}{l}\text { Proportional } \\
\text { Sample }\end{array}$ & Sub-Location & $\begin{array}{l}\text { Female } \\
\text { Population }\end{array}$ & $\begin{array}{l}\text { Proportional } \\
\text { Sample }\end{array}$ \\
\hline Gatina & 21,125 & 43 & Kothidha & 4,702 & 10 \\
\hline Kawangware & 32,731 & 66 & Kanyach-Kachar & 4,129 & 8 \\
\hline & & & $\begin{array}{l}\text { Kalanya- } \\
\text { Kanyango }\end{array}$ & 7,562 & 16 \\
\hline & & & $\begin{array}{l}\text { Kobwola- } \\
\text { Kogwang }\end{array}$ & 3,529 & 7 \\
\hline Total & 53,856 & 109 & & 19,922 & 41 \\
\hline
\end{tabular}

Source: Kenya National Bureau of Statistics Census Report, 2009.

\section{Sampling of Respondents}

One hundred and fifty respondents were sampled from all labor market categories. The investigator identified the first respondent using simple random sampling technique. Other participants were sampled through systematic sampling technique. Through purposive sampling technique, ten key informants were sampled based on their expert knowledge about employment issues.

\section{Data Collection and Analysis}

The study was based on qualitative and quantitative research techniques to surmount the flaws or inherent partiality of applying one method. Quantitative and qualitative data were collected using a survey questionnaire and a key informants' interview guide. Quantitative data was analyzed using the Statistical Package for Social Science (SPSS). Qualitative data were analyzed thematically.

\section{Terms and Conditions of Employment}

\section{STUDY FINDINGS}

The terms and conditions discussed in this section include type of contracts, number of working hours, type of leave or off days offered and facilities offered to female employees. In 
addition equality in access to opportunities such as wages, training and promotion at work place was also examined.

\section{Contractual Arrangements}

Out of the 94 respondents who indicated that they were employed, 26 were selfemployed/running their own businesses and 10 were engaged in unpaid family work. Thus, the remaining 58 were employees in the informal sector, formal private and public institutions. Among the 58,67.2\% (39) indicated that they were having contracts in their current jobs while $32.8 \%$ (19) did not have any contract. For those who had contracts, $64.1 \%$ were working under oral contracts of unlimited duration, 33.3\% had permanent written contracts and only $2.6 \%$ had temporary written contracts. As shown in Table 4.14, majority of those who had written contracts were employed formally in government institutions whereas most of those who were in the formal private and informal sector worked under oral contracts. Buchmann et.al. (2010) argues that oral contracts are usually adopted by employers in order to create flexible jobs to enable them deal with highly fluctuating product markets. Additionally, some employers resort to oral contracting in order to avoid employment costs such as taxation and dismissal costs; hence, they are able to hire and fire employees easily. However, such job arrangements are in most instances unstable and characterized by lower pay, lower job security, and less favorable working conditions, which can deter women from accessing them.

Table 4: Type of employment contract by Market category

\begin{tabular}{|l|l|l|l|l|}
\hline Type of employment contract & \multicolumn{3}{|c|}{ Market category } & Total \\
\cline { 2 - 5 } & $\begin{array}{l}\text { Formal } \\
\text { Government }\end{array}$ & $\begin{array}{l}\text { Formal } \\
\text { Private }\end{array}$ & $\begin{array}{l}\text { Informal } \\
\text { Sector }\end{array}$ & \\
\hline $\begin{array}{l}\text { Oral contract of unlimited } \\
\text { duration (permanent) }\end{array}$ & 2 & 13 & 10 & 25 \\
$\begin{array}{l}\text { Written contract (permanent) } \\
\text { Written contract (temporary) }\end{array}$ & 10 & 3 & 0 & 13 \\
Total & 0 & 1 & 0 & 1 \\
\hline
\end{tabular}

Source: Field Data, 2015

\section{Number of working hours}

The study examined the number of hours that a respondent was required to work in a day in their current job. The mean number of working hours was 9.58 hours for all the respondents. However, for the formally employed respondents in the private sector, the mean number of working hours was 10 hours amounting to 60 hours in a week, which is higher than the normal working hours as stipulated in the Kenya labor laws. According to the Kenya labor laws, a normal working week should not consist of more than 52 hours spread over six days. Therefore, the pre-fixed long working hours in the private sector may possibly make it difficult for female youths who were already having additional domestic responsibilities to balance between domestic and market work. Consequently, some women may resort to other employment forms such as self-employment in the informal sector with flexible working schedules.

The study also sought to find out whether the respondents worked beyond the stipulated working hours and the form of compensation provided for the extra hours. $67.2 \%$ did not work overtime. Among the 32.8\% who worked overtime, $63.2 \%$ indicated that they were compensated either in monetary form or in form of leave days for extra hours worked while $36.8 \%$ stated that they did not receive any form of compensation for working extra hours. Lack 
of compensation for overtime is a clear indication that some of the employers were not complying with the labor laws, which requires that an employee be paid for any time worked in excess of the normal weekly hours.

\section{Leave/off days Provision}

Majority of the respondents stated that they were offered leave/off days (96.6\%) and a few (3.4\%) were not having such provisions. However, only some of the respondents stated that they had provisions for specific type of leaves such as maternity, sick leave and annual leave. The number of days offered for each leave differed among the respondents. As observed from Table 5, the mean number of days for maternity, sick leave and annual leave was 83.08, 8.74 and 32.15 days respectively. Among the respondents who had leave provisions, only $10.7 \%$ stated that their employers do not allow them to fully utilize their leave days.

Table 5: Min, max \&mean no. of days per leave

\begin{tabular}{|l|l|l|l|l|l|}
\hline Type of Leave & $\mathrm{N}$ & Minimum & Maximum & Mean & Std. Deviation \\
\hline $\begin{array}{l}\text { Number of days for } \\
\text { maternity leave }\end{array}$ & 13 & 30 & 90 & 83.08 & 17.974 \\
$\begin{array}{l}\text { Number of days for } \\
\text { sick leave }\end{array}$ & 23 & 1 & 14 & 8.74 & 4.760 \\
$\begin{array}{l}\text { Number of days for } \\
\text { annual leave }\end{array}$ & 20 & 14 & 60 & 32.15 & 12.119 \\
\hline
\end{tabular}

Source: Field Data, 2015

Analysis of the form of employment and type of leave offered indicated that few of the respondents employed in the private sector had provisions for maternity leave, sick leave and annual leave as summarized in Table 6 These findings indicate poor compliance with labor regulations by the private sector firms/institutions where the respondents worked. This can be attributed to the fact that most of the private formal sector respondents were drawn from small private formal firms, which may not have acquired the capacity to fully implement all the labor laws. However, in general ILO (1998), submitted that despite a number of countries ratifying different labor laws, the difference between law and practice remained wide, consequently jeopardizing women employment.

Table 6: Employment Form and Number of respondents offered specific Leave

\begin{tabular}{|l|l|l|l|}
\hline Employment Form & $\begin{array}{l}\text { No. of respondents } \\
\text { offered maternity leave }\end{array}$ & $\begin{array}{l}\text { No. of respondents } \\
\text { offered sick leave }\end{array}$ & $\begin{array}{l}\text { No. of } \\
\text { respondents } \\
\text { offered annual } \\
\text { leave }\end{array}$ \\
\hline $\begin{array}{l}\text { Formally employed } \\
\text { (Government) }\end{array}$ & 10 out of 12 & 8 out of 12 & 12 out of 12 \\
\hline $\begin{array}{l}\text { Formally employed } \\
\text { (private) }\end{array}$ & 3 out of 18 & 8 out of 18 & 8 out of 18 \\
\hline $\begin{array}{l}\text { Informally } \\
\text { employed(private) }\end{array}$ & 0 out of 28 & 7 out of 28 & 0 out of 28 \\
\hline
\end{tabular}

Source: Field Data, 2015

\section{Facilities Offered to Female Employees}

The study also investigated whether there was provision of facilities to cater for the needs of women employees who were expectant, breast-feeding or had young children. All the 
respondents indicated that they had no such provisions at their places of work. However, only $20.7 \%$ of the respondents felt that lack of such facilities was as a challenge to them. This was due to the fact that some of the respondents were not expectant, breastfeeding or having young children. The respondents who had young children reported that they used alternative coping mechanisms, such as employing house helps, leaving their children in daycare facilities and relying on the assistance of relatives and friends to enable them balance between employment and childcare work. Those who could not find house helps, suitable day care facilities and assistance of relatives faced a number of challenges in juggling employment and care giving work. For instance, $33.3 \%$ of the respondents indicated that they were not able to provide adequate care for their children, while $16.7 \%$ noted that they were usually disrupted from work. These challenges hindered the participation of women in the labor market.

\section{Access to Opportunities at Work Place}

The study investigated whether the female youths who were employed had equal opportunities to their male counterparts in the same level at work place. $72.4 \%$ indicated that they had equal opportunities in regard to wages, training and promotions whereas $15.5 \%$ had no idea about the same. Only $6.9 \%$ submitted that they did not have equal opportunities to their male counterparts. They attributed this scenario to difference in experience, skills, education and favoritism. This concurred with previous studies such as Dabalen (2000) who reported that in Kenya, women with least skills saw their position worsen relative to men with similar skills.

\section{Social Networks}

Social networks have been important channels through which information about job openings and other related information are shared among various firms and job seekers. Social networks act as a link between jobseekers and employers. Currently, a number of people are using personal connections such as friends and family members to find job opportunities. It is against this background that the study sought to investigate the types of social networks through which respondents accessed job related information.

\section{Membership to Associations}

The study inquired whether the respondents belonged to any association through which they could access information about employment issues. According to the findings, more than half (62.7\%) of the respondents stated that they belonged to at least one association. $3.2 \%$ belonged to professional associations, 5.3\% workers union, 10.6\% associations of former classmates, $28.7 \%$ church group, $56.4 \%$ chama/merry-go round and $14.9 \%$ belonged to youth groups. The results further showed that majority of the respondents in all market categories as shown in Table 4.18belonged to chamas/merry-go round and church groups, which are groupings used by women not only to meet their financial needs but also to find emotional and social support. These findings correspond to those of Ibarra (1993) \& Ibarra (1997) quoted in Stallings (2008), who stated that women have a greater number of expressive ties and relationships that provide emotional and social support. However, Ibarra (1997) argues that such ties, which are expressive in nature does not provide much job related information compared to male ties and relationships that are instrumental. 
Table 7: Type of Associations and Market Category

\begin{tabular}{|c|c|c|c|c|c|}
\hline $\begin{array}{l}\text { Type of } \\
\text { Associations }\end{array}$ & $\begin{array}{l}\text { Formal } \\
\text { Public }\end{array}$ & $\begin{array}{l}\text { Formal } \\
\text { Private }\end{array}$ & $\begin{array}{l}\text { Informal } \\
\text { sector }\end{array}$ & $\begin{array}{l}\text { Unpaid family } \\
\text { work }\end{array}$ & Unemployed \\
\hline $\begin{array}{l}\text { Professional } \\
\text { associations }\end{array}$ & 2 out of 9 & 0 out of 15 & 1 out of 30 & 0 out of 7 & 0 out of 32 \\
\hline Workers Union & 4 out of 9 & 0 out of 15 & 1 out of 30 & 0 out of 7 & 0 out of 32 \\
\hline $\begin{array}{l}\text { An association of } \\
\text { former } \\
\text { classmates }\end{array}$ & 0 out of 9 & 1 out of 15 & 1 out of 30 & 0 out of 7 & 8 out of 32 \\
\hline Church Group & 2 out of 9 & 6 out of 15 & 3 out of 30 & 1 out of 7 & 15 out of 32 \\
\hline $\begin{array}{l}\text { Chama Merry go } \\
\text { Round }\end{array}$ & 6 out of 9 & 12 out of 15 & 26 out of 30 & 0 out of 7 & 9 out of 32 \\
\hline Youth Group & 0 out of 9 & 0 out of 15 & 0 out of 30 & 5 out of 7 & 9 out of 32 \\
\hline
\end{tabular}

Source: Field Data, 2015

\section{Reliance on Social Networks for Accessing Job Related Information}

The study also inquired whether the respondents relied on their networks to access job related information owing to the fact that a number of employers usually prefer hiring through referrals. For instance, the private sector employers interviewed in Dagoreti and Homa-bay sub-counties submitted that they usually rely on referrals for recruitment apart from using formal channels due to their efficiency and effectiveness. Referrals are also preferred due to the presumption that "good people refer good people". Therefore, this is an indication that the type of networks one is part of can play a significant role in determining their access to formal job opportunities. Table, provides a summary of the number of respondents who relied on their networks across the market categories.

Table 8: Reliance on Networks by Market Categories

\begin{tabular}{|c|c|c|c|c|c|c|}
\hline \multirow{2}{*}{$\begin{array}{l}\text { Reliance } \\
\text { on } \\
\text { Network } \\
\text { S }\end{array}$} & \multicolumn{5}{|c|}{ Market Category } & \multirow[t]{2}{*}{ Total } \\
\hline & $\begin{array}{l}\text { Formal } \\
\text { public }\end{array}$ & $\begin{array}{l}\text { Formal } \\
\text { private }\end{array}$ & $\begin{array}{l}\text { Informal } \\
\text { sector }\end{array}$ & $\begin{array}{l}\text { Unpaid } \\
\text { family } \\
\text { work }\end{array}$ & $\begin{array}{l}\text { Unemploye } \\
\text { d }\end{array}$ & \\
\hline Yes & 4 & 13 & 24 & 5 & 34 & $80(53.3 \%)$ \\
\hline No & 8 & 8 & 27 & 5 & 22 & $70(46.6 \%)$ \\
\hline Total & 12 & 21 & 51 & 10 & 56 & $\begin{array}{l}150 \\
(100 \%)\end{array}$ \\
\hline
\end{tabular}

Source: Field Data, 2015

Analysis of respondents' reliance on networks showed that $53.3 \%$ of them relied on their social networks to access job related information whereas $46.7 \%$ stated that they did not rely on their networks. Job vacancies were the most accessed through social networks as reported by $78.6 \%$ of the respondents. $24.1 \%$ accessed information on training opportunities whereas internships, job referrals and volunteering opportunities were the least accessed through social networks. In addition to networks, others also relied on formal channels to access job related information. The findings showed that $57.3 \%$ of the respondents did not use formal channels to access information on employment opportunities whereas $42.7 \%$ used the formal channels. The formal channels used by the respondents include company websites, newspapers, job advertising boards/websites and recruitment agencies. The mostly used formal channels were newspapers and job advertising boards/websites. They attributed their preference for newspapers and job advertising websites/boards to ease in access, reliability and efficiency. Others also indicated that they occasionally used the channels due to difficulty in accessing them and because they are expensive. 
Further analysis as to whether respondents relied on specific network categories such as close and distant family members, close friends and acquaintances revealed that 112 out of the 150 respondents relied on at least one of the specific categories. Acquaintances was the only category that majority $(86.6 \%)$ of the respondents did not rely upon or relied less often. Majority (68.7\%) relied on close family members and close friends $(70.6 \%)$, which are regarded as strong/close introverted relationships. However, such ties/networks have been considered to transmit redundant information as opposed to extroverted friendship links that constitute richer information sources and transmit diversified information (Calvo-Armengol, 2005). Hence, minimal reliance on acquaintances is a clear indication that the respondents had limited information access as they only relied on those whom they had close relation. The results concerning the respondents' networks shows that their networks may not be very effective in accessing important job opportunities in the various sectors in the labor market because most of them belonged to close introverted and expressive networks which have been considered less powerful in regard to accessing market related information.

\section{CONCLUSION}

The study findings pointed out that labor market institutions had a great influence on female youths' access to formal employment in the private sector. The institutions examined included terms and condition of employment and the role of social networks in accessing labor market information. First, contractual arrangements were examined and the study showed that majority of those who had written contracts were employed formally in government institutions whereas majority of those who were in the formal private and informal sector worked under oral contracts. Oral contracts however subjected women workers to poor working conditions such as, poor remuneration, lack of job security, and unpaid leave. Second, the study examined the number of hours the respondents worked and established that the mean working hours for the formally employed respondents in the private sector was sixty hours in a week. This figure was higher than the normal working hours stipulated in the Kenya labor laws. Furthermore, very few respondents had provisions for specific leaves such as maternity leave, annual vocation leave, and sick leave. Therefore, poor terms and conditions of service in the private sector hindered female youths from accessing jobs. Third, analysis of the respondent's networks established that they had various types of social networks. The results indicated that more than half of the respondents belonged to at least one association with majority belonging to a chama/merry go rounds and church groups. This indicated that most of the respondents relied on expressive relationships/ties, which did not provide adequate labor market information. Therefore, social networks did not provide meaningful support to female job seekers. The following recommendations were drawn from the study findings.

\section{RECOMMENDATIONS}

I. The government should collaborate with the private sector in creating programs aimed at enhancing access to labor market information and career guidance and counseling. In so doing, female youths who have less powerful networks and who are not able to access formal job search channels will be able to easily access labor market information.

II. Second, private sector employers should adopt better terms of employment, for example, they should provisions for paid maternity leave, overtime allowances and written contracts. In addition, private firms should provide flexible working hours to female workers to enable them juggle motherhood and work.

III. The government should develop and ensure full implementation of gender sensitive labor laws in the private and public sectors. 
IV. Trade unions in Kenya should advocate better terms of service for women workers in the private sector. For example, they should regularly monitor the working conditions in the private sector and bargain for better terms of service for workers.

\section{References}

Bercherman, G. (2013). Labour Market Institution: A Review of Literature. Washington, DC: The World Bank. Calvo-Armengol, A. (2005). Social Networks and Labour Market Outcomes. Bercelona: Centre De Recerca En Economia Internacional (CREI).

Corner, L. (2011). Women and the Formal Economy. Australian Agency of International Development.

Fontana, M., \& Paciello, C. (2007). Labour Regulations and Anti-discrimination Legislation: How do they Influence Gender Equality in Employment. Brighton: Institute of Development Studies Sussex.

Hensvik, L., \& Skans, O. N. (2003). Networks and Youth Labour Market Entry. Uppsala: Institute for Evaluation of Labour Market and Evaluation Policy.

Holmlund, B. (2013). What do Labour Market Institutions do? Department of Economics, Uppsala University. KIPPRA. (2013). A Comparative Study on Public-Private Sector Wage Differentials in Kenya. Nairobi: KIPPRA. KNBS. (2009). Population and Housing Census 2009. Nairobi: Government Printer.

Kucera, D. (2002). Core Labour Standards and Foreign Direct Investment. International Labour Review, 141 (1-2).

Rodgers, Y., \& Berik, G. (2006). Asia's Race to Capture Post-MFA Markets: A Snapshot of Labour Standards Compliance and Impacts on Competi. Asian.

Sanja, K., \& Breslin, J. (2010). Women's Rights in the Middle East and North Africa: Progress and Resistance. New York: Freedom House.

Sirin, S. (2003). Women Reconciling Paid and Unpaid Work in a Confucian Welfare State: The Case of South Korea. Social Policy and Administration , 37 (4), 342-360.

World Bank. (2010). Women's Economic Opportunities in the Formal Private Sector in Latin America and the Caribbean. Washington, DC: The World Bank. 